\title{
HIGH-QUALITY DNA FROM PEAT SOIL FOR METAGENOMIC STUDIES: A MINIREVIEW ON DNA EXTRACTION METHODS
}

\author{
Muhamad Aidilfitri Mohamad Roslan, Mohd Azrul Naim Mohamad, Suhaila Mohd Omar* \\ Department of Biotechnology, Kulliyyah of Science, International Islamic University Malaysia, Kuantan Campus, Jalan Sultan Ahmad Shah, Bandar Indera \\ Mahkota, 25200, Kuantan, Malaysia
}

*Corresponding author email: osuhaila@iium.edu.my

This is an open access article distributed under the Creative Commons Attribution License, which permits unrestricted use, distribution, and reproduction in any medium, provided the original work is properly cited

\section{ARTICLE DETAILS}

\section{Article History:}

Received 3 July 2017

Accepted 3 October 2017

Available online 1 December 2017

Keywords:

Traffic accidents, volunteered geographic information, hierarchical analysis, accidentprone points, multi-criteria decision making.

\section{ABSTRACT}

The understanding of microorganism's biodiversity in the peatland soil through non-cultivation based approach provide important inputs towards prediction of the ecosystem response towards the changing environment. The challenge that hindered the success to obtain high quality DNA from peat soil lies in the physicochemical characteristics such as low $\mathrm{pH}$ and high humic acid content. There are two general approaches that have been extensively applied for soil microbial DNA extraction, which are direct DNA extraction protocol and indirect DNA extraction protocol. The only step differentiate between these two protocols is the later includes additional cell separation method from soil micro-aggregates preceding DNA extraction process. Therefore, several improved and modified methods in conventional DNA extraction and purification methods are reviewed in this paper to cater all the highlighted issues as to obtain high-quality DNA for peatland metagenomics soil studies.

\section{INTRODUCTION}

Soil is a huge reservoir of carbon sources and organic matter, providing valuable nutrient-rich habitat for growth and energy for diverse organism. The biological interaction amongst soil indigenous microorganisms is significant to maintain soil function, composition and fertility. In estimation, up to $10^{8}$ microbial cells were found in a gram of bulk soil with at most 100 species diversity [1]. The role and complexity of soil microbial metabolisms and interactions have been broadly exploited with respect to various biotechnological applications such as plant microbial inoculation, bioremediation, enzyme isolation and bioactive compounds production [2-9].

The microbial abundance has been extensively explored by the classical laboratory cultivation techniques which however bears only limited biodiversity of approximately less than $1 \%$ cultivable microbes from the natural environments [10-12]. These conventional culture-dependent methods heavily rely on the optimum supply of nutrient sources, growth media and other physical and chemical parameters such as $\mathrm{pH}$, temperature and metal ions concentration that suit optimally to only certain groups of microorganisms hence dramatically underestimating the accurate number of microorganisms in the nature. The limitation of these growth techniques hinders the process of comprehensive soil microbial community analysis making it almost impossible and practically tedious to uncover more uncultivable and novel microorganism species.

To overcome such limitations, the later development of rapid and direct access of genetic material from environmental samples without cultivation has been introduced. The term metagenomics is then used to describe the study of the collective unknown genetic material which give insights not just into the taxonomy diversity of the environmental samples but also their ecological function [13]. This discovery has revolutionized the way we perceive and understand the microbial world due to their ability to expose the previously unknown microscopic life diversity. However, the reliability and robustness of the metagenomics analyses nevertheless depends on the quality of DNA isolated.

The fundamental of DNA extraction protocol comprises of several main and optional procedures which are cell disruption, membrane lipid removal, protein and RNA elimination, nucleic acid purification and precipitation. Those steps may apply combinations of all or some of physical/mechanical, chemical, and enzymatic treatments throughout the process to achieve the main objective of any DNA extraction, which is high purity, quantity and quality of DNA yield suitable for the subsequent applications such as cloning or next-generation sequencing.

Since the late 80 's, various soil nucleic acid extraction methods have been published and continue to be revised and modified [14]. Despite the improvement and introduction of new techniques from time to time, there is still no standard methods which are universally applicable for all soil types [15]. This is because specific optimization in the extraction and purification techniques are required for specific soil properties and physicochemical characteristics [16-18].

For example, the challenge of DNA extraction from peat soil is due to its unique composition of a thick accrued remains of animals and plant components such as roots, leaves and woods which are also attributable to its highly acidic, high organic matter, anoxic and low-nutrient soil condition [19]. These soil characteristics demand for a specific strategy in isolating high quality DNA. In fact, the extreme physicochemical properties of peat soil was reported to restrain the effort to explore the diversity of its soil microbiota using cultivation strategies, but was more successful through direct soil DNA extraction $[20,21]$. Therefore, this review highlights the modification and improvement in soil DNA extractions and purification techniques as well as their effectiveness in obtaining high quality DNA particularly from peatland soil for metagenomic study.

\section{PEAT SOIL EDAPHIC FACTORS}

Peatland is the general term to categorize peat-covered terrain which comprises (mostly) of several main wetland ecosystems such as fens, bogs 
and swamp forests based on physiognomics and dominance over the structure and vegetation [19]. These oligotrophic or mesotrophic ecosystems acquire different soil physicochemical characteristics based on the geographical area, climate, weather and other complex environmental factors. In general, peat soil has low $\mathrm{pH}$ ranging from 2 to 5 , due to amassing of plant litter which contributes to the abundance organic matter and humic and fulvic acids in the waterlogged soil [22]. McLaughlin and Webster described the acidification and alkalinization of fen peatland of northern Ontario occur based on the interactions between water table level and peat cation exchange [23].

The acidification and alkalinization cycle based on the climate condition results in the peatland progression from intermediate to poor fens. Poor fens or peat bogs are characterized by domination of oligotrophic species such as Sphagnum mosses and are commonly ombotrophic, acidic and nutrient-poor by nature [24]. Peat accumulation and its lowdecomposition rate correspondingly upsurge the soil acidity and contribute to nutrient-deficient conditions especially in peat swamp forests where there are no new nutrient inputs from adjacent rivers $[25,26]$. Peat water of tropical peat swamp forest is acidic and dark color due to high concentrations of tannins and humic acids [27].

Studies has shown that there is an inverse relationship between organic content and PCR performance which muchly due to humic content in highorganic soil $[16,28]$. Tebbe and Vahjen discovered that humic acids and DNA-coextracted substances interfere with DNA-DNA hybridization, restriction enzymes digestions, PCR and transformation process [29]. Moreover, DNA yield from peat soils was perpetually low as compared to other type of soils [30].

\section{SOIL MICROBIAL DNA EXTRACTION}

The protocols used in DNA extraction strategies determine the quality of the DNA extracted. In microbiome studies such as in metagenomics, high quality DNA is needed in clone library construction and DNA sequencing for obtaining sufficient representatives of all cells present in the sample [31]. Generally, DNA extraction methods can be categorized into two different approach namely direct (in situ) DNA extraction and indirect (ex situ) DNA extraction methods $[14,32]$. These protocols are differentiated by the preliminary step prior to nucleic acid extraction whereby the former involves cell lysis within the soil matrix while the later involves dislodgement of cell from the sample followed by the subsequent cell lysis. Both methods nevertheless have their own strength and weaknesses in terms of the quantity and quality of the DNA extracted.

\subsection{Direct DNA extraction}

\subsubsection{In situ cell lysis}

Cell lysis is the primary step of DNA extraction which plays a major role in determining the extraction end results. The concept of this step is to rupture microbial cell wall hence releasing the intracellular nucleic acids. Mechanical disruption has been historically used for many years especially in direct extraction methods considering the ability to access whole microbial cell within soil micro-aggregates [33]. Harsh physical or mechanical treatment for instance freezing and thawing cycles, microwave heating, manual liquid nitrogen grinding, bead-beating or sonication are usually applied in this method [16, 28, 34-44].

Even though the efficiency of those methods to lyse bacterial cells has been proven, there are several reports which also highlight the drawbacks of physical treatment towards the quality and quantity of DNA. For example, it was found that the use of bead-beating technique with longer time will contribute to more DNA yield but will also cause more DNA shearing and increasing fractions of low-molecular weight DNA as compared to sonication, freezing and thawing [45]. In comparison to bead-beating, sonication is less efficient as it causes more DNA shearing [43]. On the other hand, Karakousis et al. stated that sonication and mortar and pestle techniques were recorded with almost $100 \%$ efficiency in breaking fungal hyphae and conidia [46].

In another bead-beating comparative study, a researcher reported that the bead-beating extraction used on Osterliwald soil (highest clay and organic matter content) at the $5 \mathrm{~m} / \mathrm{s}$ speed setting successfully produced the highest yield of DNA with $6.5 \pm 0.1 \mathrm{~kb}$ fragment size [41]. The challenge to achieve efficient cell lysis in clay-rich soil lies in the tendencies of DNA to bind with clay colloids which later lead to low DNA yield [16]. In one of the study to increase yield of DNA extracted directly from soil, a scientist also add RNA in the extraction buffer to saturate the nucleic acid adsorption sites of soil colloids. They found a positive effect of RNA treatment, but even for the higher RNA concentrations (100 $\mathrm{mg} \mathrm{g}^{-1}$ [dry weight] of soil), the recovery rate of the DNA never exceeded 3\%. [47]

Physical methods are usually combined with chemical treatment by using detergent to assist the slurry homogenization and cell lysis along with the appropriate enzymes to remove lipids and proteins. For instance, by using a combined chemical-enzymatic-mechanical lysis, a group researcher found a significant difference in the lysis efficiency and the DNA yield as compared to other combined methods which are chemical-enzymatic and chemical-mechanical [48]. A strong anionic detergent such as sodium dodecyl sulfate (SDS) is frequently used together with several other chelating agents such as ethylenediaminetetraacetic acid (EDTA), sodium chloride $(\mathrm{NaCl})[16,49,50]$. Sodium phosphate buffer, or Tris commonly used together to neutralize negative metal ions (magnesium and calcium ions) to maintain DNA integrity. However, according to Zhou et al. the clay content in soil will affect significantly the efficiency of SDS-based cell lysis and will not be as effective to at least some gram-positive bacteria even with the heating and high-salt treatment [16].In addition, the use of phosphate buffer saline (PBS) and mannitol in the lysis buffer has been reported to improve DNA yield and purity [51].

The substitution of harsh physical lysis by enzymatic and chemical lysis has always resulted in the production of larger size of DNA fragment. This is proven by Pang et al who managed to isolate up to $290 \mathrm{~kb}$ DNA fragments when they replaced bead-beating with chemical-enzymatic lysis [52]. A comparable approach was also applied by some researcher by applying their newly developed alkaline lysis method and successfully obtained up to $80 \mathrm{~kb}$ DNA fragment size [53].

\subsubsection{DNA purification}

Impurities in DNA such as protein and humic acid contamination will lead to inaccurate measurement of DNA concentration and could potentially inhibit subsequent molecular processes and analysis. Thus, elimination of all those impurities is a must, especially for DNA extracted directly from soil, as humic acids are commonly co-extracted during the extraction process [16].

A cationic detergents such as, cetyltrimethylammonium bromide (CTAB) or polyvinyl polypyrrolidone (PVPP) is alternatively incorporated in either lysis buffer or in a single treatment during purification process [16, 42 , 54, 55]. The addition of PVPP helps in eliminating polyphenolic compounds thus reducing contaminants especially in soil sample which are rich in plant remains such as rhizosphere soil although there are some reports that it will cause reduction in DNA yield. Anionic surfactant like Nlauroyl sarcosine is sometimes applied to improve DNA extraction [5657].

To improve deproteination and cell lysis, specific enzymes are added together in the extraction buffer or separately in different enzymatic treatment. The most frequently enzyme used is lysozyme which catalyze hydrolysis of peptidoglycan in bacterial cell walls especially to Grampositive bacteria $[28,43,49,58]$. Other enzymes used in DNA extraction include achromopeptidase and proteinase $\mathrm{K}[59,60]$.

In one experimental comparison between lysozyme treatment and microwave heating method, Orsini et al. claimed that the former produced more DNA yield with larger fragment size of approximately $20 \mathrm{~kb}$ [40]. Almost similar size of DNA fragments was obtained from termite nest soil by incorporating lysozyme and the crude ligninolytic enzyme extract from Ganoderma sp. rckk-02 in the lysis buffer [61]. This newly developed enzymatic treatment was reported to successfully recover $90 \%$ of DNA after purification with reduction of humic acid up to $81 \%$.

Most DNA purifications or precipitations are achieved by using combinations of high-salt solution such as sodium chloride, magnesium chloride, potassium acetate, sodium acetate, followed by further precipitation with organic solvent such as ethanol, isopropanol or chloroform $[32,53,62]$. Roose-Amsaleg suggested to use polyethyleneglycol (PEG) instead of ethanol or isopropanol so that the final volume of eluted sample can be reduced to obtain concentrated DNA [36].

DNA purification by using cesium chloride density gradient centrifugation $(\mathrm{CsCl})$ with incorporation of ethidium bromide has been effective in permitting subsequent restriction enzymes digestion of purified nucleic acids [14]. This is confirmed by some researcher as they obtained relatively pure DNA by using CsCl-based isopycnic gradient [56]. Further purification of DNA can be conducted by using hydroxyapatite column chromatography with incorporation of sodium phosphate buffer and urea with specific concentration $[14,55]$. Although more purified DNA was obtained by using both $\mathrm{CsCl}$ gradient centrifugation followed by 
hydroxyapatite column chromatography consecutively, these methods unfortunately were reported to cause DNA loss [55].

\subsection{Indirect DNA extraction}

\subsubsection{Soil dispersion and cell separation}

The main objectives of indirect approach in DNA extraction protocol are to disperse soil aggregates and to separate microbial cells from soil particles by using various available methods prior to DNA extraction. This approach is observed to be superior than the direct lysis method with respect to the ability to minimize co-extraction of extracellular DNA and produce larger fragment DNA with a high degree of purity as well as to specifically target on prokaryote DNA [63].

The most common physical treatment used for soil dispersion and homogenization includes Waring blender dispersal, sonication and centrifugation with inclusion of chemical treatment such as Chelex 100, PVPP or other salts and buffers [10, 32, 43, 64-68]. Nycodenz density gradient centrifugation (NDGC) has been used widely for bacterial cell separation method which precedes with low-speed centrifugation (LSC) to eliminate course soil particles, and later with high-speed centrifugation (HSC) using ultra- centrifuge equipment to separate bacterial cells and Nycodenz solution $[56,66]$. A group researcher reported that by using NDGC, in contrary with Bakken, soil properties did not seem to bias the yield of bacterial extraction $[56,65]$.

\subsubsection{DNA extraction and purification}

In the indirect lysis protocol, DNA of the separated cells is extracted and purified using similar method as in direct extraction protocol discussed previously with the exception of harsh physical cell disruption. For example, Bertrand et al. lysed bacterial cell only by using chemical and enzymatic treatment following DNA purification using $\mathrm{CsCl}$ density gradient method and successfully isolated high-molecular weight DNA of more than $400 \mathrm{~kb}$ fragment size [56]. On the other hand, Williamson et al. has demonstrated the application of bacterial cell lysis within agarose plug with combination of chemical and enzymatic treatment and obtained a high DNA yield [57].

\subsection{Direct lysis vs indirect lysis}

According to a study, cell lysis is biased to DNA from Gram-negative cells which is easier to disrupt than Gram-positive cells [69]. Since the disruption of gram negative and gram-positive walls take place at different time, the former will be easily sheared with prolonged cell lysis treatment. Direct physical methods have been comparatively tested with respective capacity to lyse microbial cell and yielded more DNA, yet will compromise the size of DNA fragment [67] and may introduce some bias towards certain groups of microorganisms $[16,67]$.

In general, combination of harsh mechanical and other chemical and enzymatic treatment indirect lysis protocols is usually associated with severe DNA shearing thus producing low molecular weight DNA or short fragment DNA. Indirect extraction protocol on the other hand has always resulted in the high-molecular weight DNA isolation with minor or none further purification. The fragment size is an important factor as to plan the downstream process after the DNA isolation especially when cloning is involved.

Large-insert libraries have higher potential to contain complete biosynthetic pathways of antimicrobial compounds, multiple enzymes or operons encoding complex metabolisms, while small-insert libraries are common in gene products identification encoding most enzymes, or genetic determinants of antibiotic resistance [70]. Improved and modified methods of DNA extraction from soil for both direct and indirect protocols with a focus on successful isolation of large DNA fragment size are summarized in Table 1.

Table 1: Improved and modified methods with successful highmolecular weight (HMW) DNA extraction for both direct and indirect protocols from 2003-2014

\begin{tabular}{|c|c|c|c|c|c|c|}
\hline $\begin{array}{l}\mathbf{N} \\
\mathbf{o}\end{array}$ & $\begin{array}{l}\text { Soil origin/ } \\
\text { type }\end{array}$ & $\begin{array}{l}\text { Pre- } \\
\text { treatment/ } \\
\text { cell } \\
\text { separation }\end{array}$ & Cell lysis & $\begin{array}{l}\text { Extraction } \\
\text { buffer }\end{array}$ & $\begin{array}{l}\text { Purification } \\
\text { technique }\end{array}$ & Ref \\
\hline & \multicolumn{6}{|c|}{ Direct extraction (DNA fragment size: $25 \mathrm{~kb}-290 \mathrm{~kb}$ ) } \\
\hline 1. & $\begin{array}{l}\text { High altitude } \\
\text { region soil of } \\
\text { Northwestern } \\
\text { Himalayas, } \\
\text { India }\end{array}$ & Not available & Soil suspension & $\begin{array}{l}\text { CTAB, Tris, } \\
\mathrm{NaH}_{2} \mathrm{PO}_{4} \text {, } \\
\text { EDTA, NaCl, } \\
\text { modified } \\
\text { method of } \\
\text { Zhou et al. } \\
\text { [16], [71] }\end{array}$ & Not specified & [72] \\
\hline
\end{tabular}

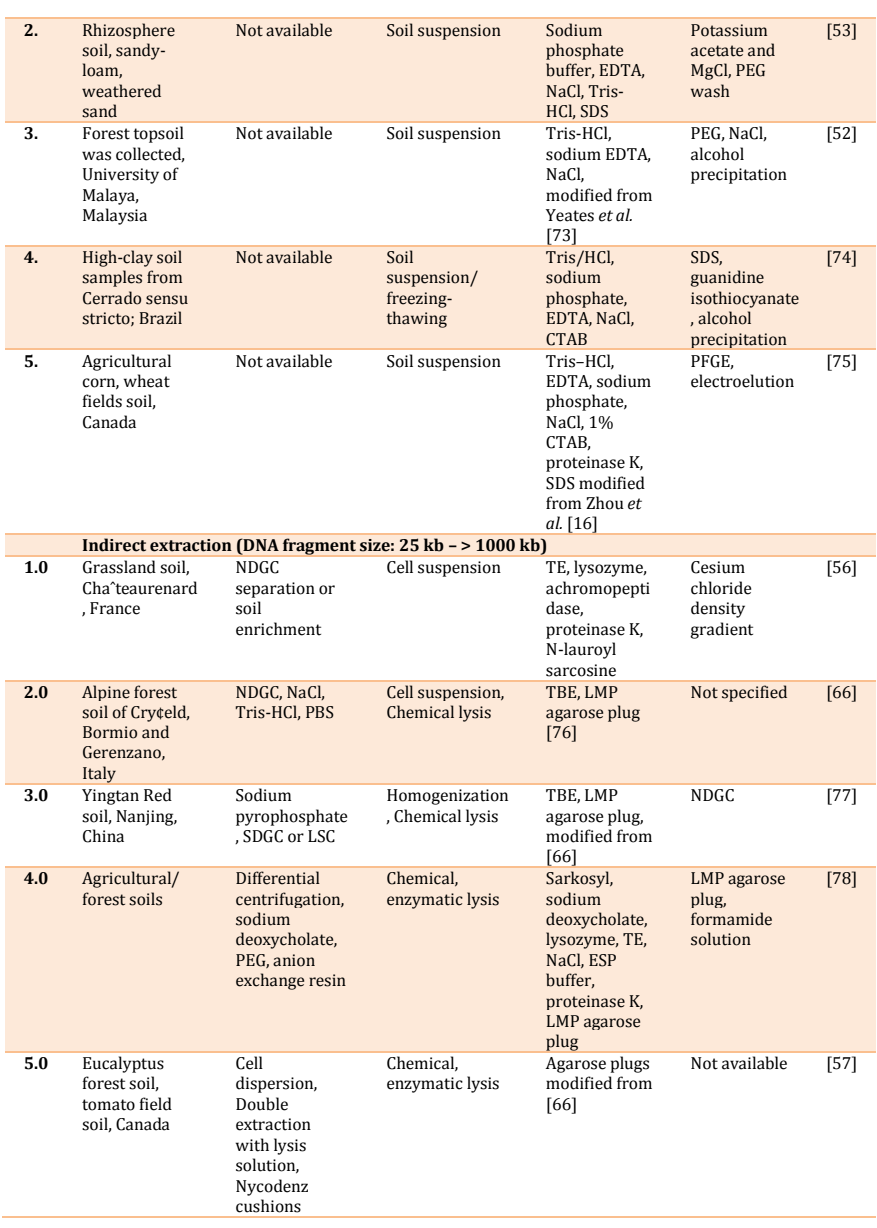

\section{SOIL ENRICHMENT METHOD}

Soil enrichment methods are occasionally incorporated before cell separation or DNA isolation in order to promote and improve microbial population by introducing specific substrate or medium in a controlled conditions [79-81]. For example, some researcher supplied soil culture with a single amide or a mixture of different aromatic and non-aromatic acetamide and glycine amide derivatives as the sole nitrogen source to selectively promote the growth of amidase-exhibiting organisms [79]. Mori et al. performed enrichment culture in modified M9 minimal medium with a carbon source of either microcrystalline cellulose (Avicel $®$ ) or unbleached hardwood kraft pulp which results in the detection of cellulase and xylanase gene from the metagenomic libraries [80]. This strategy practically confines the expected clone libraries size and has been proven to increase the possibility of detecting genes of interest and other target or uncommon activities $[81,82]$.

\section{METAGENOMICS STUDIES OF PEATLAND SOIL}

The rapidly expanding study of soil DNA which also popular as soil metagenomics has generated unprecedented ability to obtain rich information that provides insights into taxonomic and functional diversity of soil microorganisms. The early work on metagenomics studies of soil involved the extraction of environmental DNA followed by insertions into various vectors (plasmids, BACs, and cosmids) and propagation in Escheria coli [83]. This was complementary with shotgun and amplicon sequencing technologies that allowed direct DNA sequencing and produced up to 100 billion base pairs of sequence data [84].

Both metagenomics library and DNA sequencing resulted with complex genomic and DNA sequence libraries that provide access to the entire content of soil metagenome [83]. A metagenomic study of peatland soil with acidic, high organic accumulation and low mineral content provide insights into microbial specialization and functions in this unique terrestrial ecosystem that rapidly diminishing due to conversion into agricultural land or make way for urbanization [85]. The recent metagenomics studies involving peatland soil from Thailand, Siberia, Malaysia, Alaska and Sloevenia are summarized in Table $2[21,27,86-89]$.

Table 2: Published metagenomic libraries from various peatland soil (2006-2013) 


\begin{tabular}{|c|c|c|c|c|c|c|c|c|c|}
\hline No & Soil origin & Vector & Number of clones & $\begin{array}{l}\text { Avg size insert } \\
\text { (kb) }\end{array}$ & $\begin{array}{c}\text { Total } \\
\text { DNA (Mb) }\end{array}$ & $\begin{array}{l}\text { Genes of } \\
\text { interest }\end{array}$ & $\begin{array}{l}\text { Sequencing platform } \\
\text { technology }\end{array}$ & Year & Refs \\
\hline 1. & $\begin{array}{l}\text { Peat soil, Pru Toh Daeng peat swamp } \\
\text { forest, Thailand }\end{array}$ & $\begin{array}{l}\text { pTZ57R/T vector (Fermentas, } \\
\text { Vilnius, Lithunia) }\end{array}$ & $>416$ & $20-40$ & 45.9 & $\begin{array}{l}\text { Methyl-coenzyme-M } \\
\text { reductase (mcrA)genes }\end{array}$ & $\begin{array}{l}\text { 454-Life Sciences GS-FLX } \\
\text { Genome Sequencer System }\end{array}$ & 2011 & [86] \\
\hline 2. & $\begin{array}{l}\text { Peat soil, Sphagnum peat bog Bakchar, } \\
\text { West Siberia }\end{array}$ & $\begin{array}{l}\mathrm{pCR} \circledast \\
2.1, \mathrm{TA} \text { cloning kit (Invitrogen) }\end{array}$ & $>101$ & NS & NS & NS & $\begin{array}{l}\text { ABI Prism } 377 \text { DNA } \\
\text { sequencer }\end{array}$ & 2006 & [21] \\
\hline 3. & $\begin{array}{l}\text { Upper peat sediments, North Selangor } \\
\text { Peat Swamp Forest, Malaysia }\end{array}$ & $\begin{array}{l}\text { Artificial plasmid vectors (TA } \\
\text { TOPO Cloning, Invitrogen) }\end{array}$ & $>96$ & NS & NS & NS & NS & 2009 & [27] \\
\hline 4. & $\begin{array}{l}\text { Peat-swamp forest soil, Narathiwat } \\
\text { Province, Thailand }\end{array}$ & $\begin{array}{l}\text { pCC1FOS, Epicentre; pZErO-2, } \\
\text { Invitrogen; }\end{array}$ & 15,000 & $20-40$ & NS & $\begin{array}{l}\text { Lipases/ esterases } \\
\text { genes }\end{array}$ & $\begin{array}{l}\text { Pyrosequencing (Genome } \\
\text { Institute, BIOTECH, } \\
\text { Pathumthani, Thailand) }\end{array}$ & 2010 & [89] \\
\hline 5. & $\begin{array}{l}\text { Peat soil, lake basin in the Arctic } \\
\text { coastal plain near Barrow, Alaska }\end{array}$ & $\mathrm{NA}$ & $\mathrm{NA}$ & $\mathrm{NA}$ & $\mathrm{NA}$ & $\begin{array}{l}\text { Anaerobic respiratory } \\
\text { reductases; } \\
\text { Methanogenesis genes; } \\
\text { Acetogenesis genes }\end{array}$ & $\begin{array}{l}\text { GS FLX Titanium } \\
\text { Pyrosequencer }\end{array}$ & 2013 & [87] \\
\hline 6. & $\begin{array}{l}\text { Forest peat soil, Ljubljana marsh, } \\
\text { Slovenia }\end{array}$ & pGEM-T Easy vector (Promega) & $>245$ & NS & NS & $\begin{array}{l}\text { Thaumarchaeal } a m o A \\
\text { genes }\end{array}$ & NS & 2010 & [88] \\
\hline
\end{tabular}

\section{CONCLUSION}

The success of isolating quality DNA from soil relies on different method used in the extraction protocol. Both direct and indirect extraction approaches comparably have different capacity to access the soil metagenome prerequisite for various molecular applications. Direct extraction methods are perceived as an ideal approach concerning its lesslaborious, rapid, and cost-effective processes requirement. In general, these in-situ lysis methods have shown superior results in terms of DNA yield and successful discovery of more diverse assemblage of microbial soil community pattern with minimum bias. Nevertheless, the coextraction of PCR-inhibitory compounds and the high risk of DNA shear are still among the enduring challenges when dealing with DNA from direct lysis protocols.

Indirect extraction protocols contrariwise are preferred when pure and high molecular weight DNA or larger DNA fragment size is required in the subsequent molecular application. The optimization and improvement of DNA extraction protocol is critical in determining the end results of any microbial ecology studies especially in limiting the inherent bias, despite all of the soil physicochemical challenges. Besides, the isolation of quality DNA is crucial in metagenomic studies that offer wide-ranging information on microbial community structure and their ecological function in the environment especially in a unique environment such as peatland ecosystems.

\section{ACKNOWLEDGEMENT}

This project was funded by Endownment B (EDW B 14-196-1081) and Research Initiative Grant Scheme (RIGS16-320-0484) from International Islamic University Malaysia as well as Fundamental Research Grant Scheme (FRGS14-154-0395) from Ministry of Higher Education Malaysia.

\section{REFERENCE}

[1] Raynaud, X., and Nunan, N. 2014. Spatial Ecology of Bacteria at the Microscale in Soil. PLoS One, 9 (1), p. e87217.

[2] Hobbie, J. E., and Hobbie, E. A. $2006.15 \mathrm{~N}$ in symbiotic fungi and plants estimates nitrogen and carbon flux rates in arctic tundra. Ecology, 87 (4), 816-822.

[3] Abd-Alla, M.H., El-Enany, A.W.E., Nafady, N.A., Khalaf, D.M., and Morsy, F.M. 2014. Synergistic interaction of Rhizobium leguminosarum bv. viciae and arbuscular mycorrhizal fungi as a plant growth promoting biofertilizers for faba bean (Vicia faba L.) in alkaline soil. Microbiological Research, 169 (1), 49-58.

[4] Karthikeyan, R., and Kulakow, P.A. 2003. Soil plant microbe interactions in phytoremediation. Advances in Biochemical Engineering / Biotechnology, 78, 51-74.

[5] Ni, H., Zhou, W., and Zhu, L. 2014. Enhancing plant-microbe associated bioremediation of phenanthrene and pyrene contaminated soil by SDBSTween 80 mixed surfactants. Journal of Environmental Sciences, 26 (5), 1071-1079.

[6] Bains, J., Capalash, N., and Sharma, P. 2003. Laccase from a nonmelanogenic, alkalotolerant gamma-proteobacterium JB isolated from industrial wastewater drained soil. Biotechnology Letters, 25 (14), 11559.
[7] Morabbi Heravi, K., Eftekhar, F., Yakhchali, B., and Tabandeh, F. 2008. Isolation and Identification of a Lipase Producing Bacillus sp. from Soil. Pakistan Journal of Biological Sciences, 11 (5), 740-745.

[8] Ranjbariyan, A., Shams-Ghahfarokhi, M., and Razzaghi-Abyaneh, M. 2014. Antifungal activity of a soil isolates of Pseudomonas chlororaphis against medically important dermatophytes and identification of a phenazine-like compound as its bioactive metabolite. Journal de Mycologie Médicale, 24 (2), e57-e64.

[9] Gholizadeh, S. S., Baserisalehi, M., and Bahador, N. 2013. Study on bioactive compounds produced by soil origin Brevibacillus spp. Nature Environment and Pollution Technology, 12 (2), 209-214.

[10] Torsvik, V., Goksøyr, J., and Daae, F. L. 1990. High diversity in DNA of soil bacteria. Applied and Environmental Microbiology, 56 (3), 782-7.

[11] Amann, R. I., Ludwig, W., Schleifer, K. H., Amann, R. I., and Ludwig, W. 1995. Phylogenetic Identification and In Situ Detection of Individual Microbial Cells without Cultivation. Microbiology Reviews, 59 (1), 143169.

[12] Terrat, S., Christen, R., Dequiedt, S., Lelièvre, M., Nowak, V., Regnier, T., Bachar, D., Plassart, P., Wincker, P., Jolivet, C., Bispo, A., Lemanceau, P., Maron, P.A., Mougel, C., Ranjard, L. 2012. Molecular biomass and MetaTaxogenomic assessment of soil microbial communities as influenced by soil DNA extraction procedure. Microbial Biotechnology, 5 (1), 135141.

[13] Handelsman, J., Rondon, M. R., Brady, S. F., Clardy, J., and Goodman R.M. 1998. Molecular biological access to the chemistry of unknown soil microbes: a new frontier for natural products. Chemistry and Biology, 5 (10), R245-R249.

[14] Ogram, A., Sayler, G. S., and Barkay, T. 1987. The extraction and purification of microbial DNA from sediments. Journal of Microbiological Methods, 7 (2-3), 57-66.

[15] Rajendhran, J., and Gunasekaran, P. 2008. Strategies for accessing soil metagenome for desired applications. Biotechnology Advances, 26 (6), 576-590.

[16] Zhou, J., Bruns, M. A., and Tiedje, J. M. 1996. DNA recovery from soils of diverse composition. Applied and Environmental Microbiology, 62 (2), $316-22$.

[17] Harry, M., Gambier, B., Bourezgui, Y., and Garnier-Sillam, E. 1999. Evaluation of purification procedures for DNA extracted from rich organic samples: interference with humic substances. Analusis, 27 (5), 439-441.

[18] Lakay, F.M., Botha, A., and Prior, B.A. 2007. Comparative analysis of environmental DNA extraction and purification methods from different humic acid-rich soils. Journal of Applied Microbiology, 102 (1), 265-273.

[19] Rydin, H., and Jeglum, J. 2013. The Biology of Peatlands, 2e, 2nd ed. Oxford: Oxford University Press.

[20] Roslan, M.A.M., Amirudin, N.A., Abidin, Z.A.Z., Omar, S.M. 2015 Isolation of bacteria from the acidic peat swamp forest soil and their lignin degradation potential. Jurnal Teknologi, 77 (24), 77-81. 
[21] Dedysh, S.N., Pankratov, T.A., Belova, S.E., Kulichevskaya, I.S., and Liesack, W. 2006. Phylogenetic analysis and in situ identification of Bacteria community composition in an acidic Sphagnum peat bog. Applied and Environmental Microbiology, 72 (3), 2110-2117.

[22] Sagova-Mareckova, M., Cermak, L., Novotna, J., Plhackova, K., Forstova, J., and Kopecky, J. 2008. Innovative methods for soil DNA purification tested in soils with widely differing characteristics. Applied and Environmental Microbiology, 74 (9), 2902-2907.

[23] McLaughlin, J.W., and Webster, K.L. 2010. Alkalinity and acidity cycling and fluxes in an intermediate fen peatland in northern Ontario. Biogeochemistry, 99 (1-3), 143-155.

[24] Dedysh, S.N. 2011. Cultivating uncultured bacteria from northern wetlands: Knowledge gained and remaining gaps. Frontiers in Microbiology, 2, 2-3.

[25] Yule, C.M., and Gomez, L. N. 2009. Leaf litter decomposition in a tropical peat swamp forest in Peninsular Malaysia. Wetlands Ecology and Management, 17 (3), 231-241.

[26] MacKinnon, K., Hatta, G., Halim, H., and Mangalik, A. 1997. The Ecology of Kalimantan. Periplus Editions.

[27] Jackson, C. R., Liew, K. C., and Yule, C. M. 2008. Structural and functional changes with depth in microbial communities in a tropical Malaysian peat swamp forest. Microbial Ecology, 57 (3), 402-12.

[28] Ranjard, L., Poly, F., Combrisson, J., Richaume, A., and Nazaret, S. 1998. A single procedure to recover DNA from the surface or inside aggregates and in various size fractions of soil suitable for PCR-based assays of bacterial communities. European Journal of Soil Biology, 34 (2), 89-97.

[29] Tebbe, C. C., and Vahjen, W. 1993. Interference of humic acids and DNA extracted directly from soil in detection and transformation of recombinant DNA from bacteria and a yeast. Applied and Environmental Microbiology, 59 (8), 2657-2665.

[30] Zaporozhenko, E.V., Slobodova, N.V., Boulygina, E.S., Kravchenko, I.K., and Kuznetsov, B.B. 2006. Method for rapid DNA extraction from bacterial communities of different soils. Microbiology, 75 (1), 105-111.

[31] Thomas, T., Gilbert, J., and Meyer, F. 2012. Metagenomics - a guide from sampling to data analysis. Microbial Informatics and Experimentation, 2 (1), 3.

[32] Holben, W. E., Jansson, J. K., Chelm, B. K., and Tiedje, J. M. 1988. DNA probe method for the detection of specific microorganisms in the soil bacterial community. Applied and Environmental Microbiology, 54 (3), 703-711.

[33] Robe, P., Nalin, R., Capellano, C., Vogel, T. M., and Simonet, P. 2003. Extraction of DNA from soil. European Journal of Soil Biology, 39 (4), 183190.

[34] Torsvik, V. L., and Goksoyr, J. 1978. Determination of bacterial DNA in soil. Soil Biology and Biochemistry, 10 (1), 7-12.

[35] Tien, C. C., Chao, C. C., and Chao, W. L. 1999. Methods for DNA extraction from various soils: a comparison. Journal of Applied Microbiology, 86 (6), 937-943.

[36] Roose-Amsaleg, C. L., Garnier-Sillam, E., and Harry, M. 2001. Extraction and purification of microbial DNA from soil and sediment samples. Applied Soil Ecology, 18 (1), 47-60.

[37] Dedysh, S.N., Panikov, N.S., and Tiedje, J.M. 1998. Acidophilic methanotrophic communities from Sphagnum peat bogs. Applied and Environmental Microbiology, 64 (3), 922-9.

[38] Crecchio, C., Gelsomino, A., Ambrosoli, R., Minati, J. L., and Ruggiero, P. 2004. Functional and molecular responses of soil microbial communities under differing soil management practices. Soil Biology and Biochemistry, 36 (11), 1873-1883.

[39] Picard, C., Ponsonnet, C., Paget, E., X Nesme and P Simonet 1992. Detection and enumeration of bacteria in soil by direct DNA extraction and Polymerase Chain Reaction. Applied and Environmental Microbiology, 58 (9), 2717-2722.
[40] Orsini, M., and Spica, V.R. 2001. A microwave-based method for nucleic acid isolation from environmental samples. Letters in Applied Microbiology, 33 (1), 17-20.

[41] Bürgmann, H., Pesaro, M., Widmer, F., and Zeyer, J. 2001. A strategy for optimizing quality and quantity of DNA extracted from soil. Journal of Microbiological Methods, 45 (1), 7-20.

[42] Hurt, R.A., Qiu, X., Wu, L., Roh, Y., Palumbo, A.V., Tiedje, J.M., and Zhou, J. 2001. Simultaneous Recovery of RNA and DNA from Soils and Sediments Simultaneous Recovery of RNA and DNA from Soils and Sediments. Applied and Environmental Microbiology, 67 (10), 4495-4503.

[43] Krsek, M., and Wellington, E.M.H. 1999. Comparison of different methods for the isolation and purification of total community DNA from soil. Journal of Microbiological Methods, 39 (1), 1-16.

[44] Plassart, P., Terrat, S., Thomson, B., Griffiths, R., Dequiedt, S., Lelievre, M., Regnier, T., Nowak, V., Bailey, M., Lemanceau, P., Bispo, A., Chabbi, A., Maron, P.A., Mougel, C., Ranjard, L. 2012. Evaluation of the ISO standard 11063 DNA extraction procedure for assessing soil microbial abundance and community structure. PLoS One, 7 (9), e44279.

[45] De Lipthay, J.R., Enzinger, C., Johnsen, K., Aamand, J., and Sørensen, S. J. 2004. Impact of DNA extraction method on bacterial community composition measured by denaturing gradient gel electrophoresis. Soil Biology and Biochemistry, 36 (10), 1607-1614.

[46] Karakousis, A., Tan, L. D., Ellis, H., Alexiou, and Wormald, P. J. 2006. An assessment of the efficiency of fungal DNA extraction methods for maximizing the detection of medically important fungi using PCR. Journal of Microbiological Methods, 65 (1), 38-48.

[47] Frostegård, A., Courtois, S., Ramisse, V., Clerc, S., Bernillon, D., Gall, F.L., Jeannin, P., Nesme, X., and Simonet, P. 1999. Quantification of bias related to the extraction of DNA directly from soils. Applied and Environmental Microbiology, 65 (12), 5409-5420.

[48] Islam, M.R., Sultana, T., Joe, M.M., Cho, J.C., and Sa, T. 2012. Comparisons of direct extraction methods of microbial DNA from different paddy soils. Saudi Journal of Biological Sciences, 19 (3), 337-42.

[49] Torsvik, V. L. 1980. Isolation of bacterial DNA from soil. Soil Biology and Biochemistry, 12 (1), 15-21.

[50] Moré, M. I., Herrick, J. B., Silva, M. C., Ghiorse, W. C., and Madsen, E. L. 1994. Quantitative cell lysis of indigenous microorganisms and rapid extraction of microbial DNA from sediment. Applied and Environmental Microbiology, 60 (5), 1572-80.

[51] Fatima, F., Pathak, N., and Verma, S.R. 2014. An Improved Method for Soil DNA Extraction to Study the Microbial Assortment within Rhizospheric Region. Molecular Biology International, 518-960.

[52] Pang, M. F., Abdullah, N., Lee, C. W., and Ng, C. C. 2008. Isolation of high molecular weight DNA from forest topsoil for metagenomic analysis. Asia-Pacific Journal of Molecular Biology and Biotechnology, 16 (2), $35-$ 41.

[53] Hu, Y., Liu, Z., Yan, J., Qi, X., Li, J., Zhong, S., Yu, J., Liu, Q. 2010. A developed DNA extraction method for different soil samples. Journal of Basic Microbiology, 50 (4), 401-407.

[54] Fortin, N., Beaumier, D., Lee, K., and Greer, C. W. 2004. Soil washing improves the recovery of total community DNA from polluted and high organic content sediments. Journal of Microbiological Methods, 56 (2), 181-91.

[55] Steffan, R. J., Goksøyr, J., Bej, A. K., and Atlas, R. M. 1988. Recovery of DNA from soils and sediments. Applied and Environmental Microbiology, 54 (12), 2908-15.

[56] Bertrand, H., Poly, F., Van, V.T., Lombard, N., Nalin, R., Vogel, T.M., Simonet P. 2005. High molecular weight DNA recovery from soils prerequisite for biotechnological metagenomic library construction. Journal of Microbiological Methods, 62 (1), 1-11.

[57] Williamson, K. E., Kan, J., Polson, S. W., and Williamson, S. J. 2011. Optimizing the indirect extraction of prokaryotic DNA from soils. Soil Biology and Biochemistry, 43 (4), 736-748. 
[58] Tsai, Y. L., and Olson, B. H. 1991. Rapid method for direct extraction of DNA from soil and sediments. Applied and Environmental Microbiology, 57 (4), 1070-4.

[59] Ezaki, T., and Suzuki, S. 1982. Achromopeptidase for lysis of anaerobic gram-positive cocci. Journal of Clinical Microbiology, 16 (5), 844-846.

[60] Shahriar, M., Haque, M.R., Kabir, S., Dewan, I., and Bhuyian, M.A. 2011. Effect of Proteinase-K on Genomic DNA Extraction from Grampositive Strains. Stamford Journal of Pharmaceutical Sciences, 4 (1), 5357.

[61] Sharma, K. K., Sharma, S., Karp, M., and Kuhad, R. C. 2012. Ligninolytic enzymes improve soil DNA purity: Solution to methodological challenges of soil metagenomics. Journal of Molecular Catalysis B: Enzymatic, 83, 73-79.

[62] Laurent, F.M., Philippot, L., Hallet, S., Chaussod, R., Soulas, G., and Catroux, G. 2001. DNA Extraction from Soils : Old Bias for New Microbial Diversity Analysis Methods DNA Extraction from Soils : Old Bias for New Microbial Diversity Analysis Methods. Applied and Environmental Microbiology, 67 (5), 2354-2359.

[63] Leff, L. G., Dana, J. R., McArthur, J. V., and Shimkets, L. J. 1995. Comparison of methods of DNA extraction from stream sediments. Applied and Environmental Microbiology, 61 (3), 1141-3.

[64] Reigstad, L. J., Bartossek, R., and Schleper, C. 2011. Preparation of high-molecular weight DNA and metagenomic libraries from soils and hot springs. Methods in Enzymology, 496, 319-44.

[65] Bakken, L. R. 1985. Separation and purification of bacteria from soil. Applied and Environmental Microbiology, 49 (6), 1482-7.

[66] Berry, A. E., Chiocchini, C., Selby, T., Sosio, M., and Wellington, E. M. H. 2003. Isolation of high molecular weight DNA from soil for cloning into BAC vectors. FEMS Microbiology Letters, 223 (1), 15-20.

[67] Roh, C., Villatte, F., Kim, B., and Schmid, R. D. 2006. Comparative study of methods for extraction and purification of environmental DNA from soil and sludge samples. Applied Biochemistry and Biotechnology, 134 (2), 97-112.

[68] Jacobsen, C. S., and Rasmussen, O. F. 1992. Development and application of a new method to extract bacterial DNA from soil based on separation of bacteria from soil with cation-exchange resin. Applied and Environmental Microbiology, 58 (8), 2458-2462.

[69] Schneegurt, M. A., Dore, S. Y., and Kulpa, C. F. 2003. Direct extraction of DNA from soils for studies in microbial ecology. Current Issues in Molecular Biology, 5 (1), 1-8.

[70] Kakirde, K. S., Parsley, L. C., and Liles, M. R. 2010. Size Does Matter: Application-driven Approaches for Soil Metagenomics. Soil Biology and Biochemistry, 42 (11), 1911-1923.

[71] Stach, J. E. M. M., Bathe, S., Clapp, J. P., and Burns, R. G. 2001. PCRSSCP comparison of $16 \mathrm{~S}$ rDNA sequence diversity in soil DNA obtained using different isolation and purification methods. FEMS Microbiology Ecology, 36 (2-3), 139-151.

[72] Sharma, S., Khan, F. G., and Qazi, G. N. 2010. Molecular cloning and characterization of amylase from soil metagenomic library derived from Northwestern Himalayas. Applied Microbiology and Biotechnology, 86 (6), 1821-1828.

[73] Yeates, C., Gillings, M. R., Davison, A. D., Altavilla, N., and Veal, D. A. 1998. Methods for microbial DNA extraction from soil for PCR amplification. Biological Procedures Online, 1 (1), 40-47.

[74] de Castro, A. P., Quirino, B. F., Allen, H., Williamson, L. L., Handelsman, J., and Krüger, R. H. 2011. Construction and validation of two metagenomic DNA libraries from Cerrado soil with high clay content. Biotechnology Letters, 33 (11), 2169-2175.

[75] Cheng, J., Pinnell, L., Engel, K., Neufeld, J. D., and Charles, T. C. 2014. Versatile broad-host-range cosmids for construction of high quality metagenomic libraries. Journal of Microbiological Methods, 99 (1), 27-34.

[76] Stein, J. L., Marsh, T. L., Wu, K. Y., Shizuya, H., and DeLong, E. F. 1996 Characterization of uncultivated prokaryotes: isolation and analysis of a 40-kilobase-pair genome fragment from a planktonic marine archaeon. Journal of Bacteriology, 178 (3), 591-9.

[77] Liu, J., Li, J., Feng, L., Cao, H., and Cui, Z. 2010. An improved method for extracting bacteria from soil for high molecular weight DNA recovery and BAC library construction. The Journal of Microbiology, 48 (6), 728733.

[78] Liles, M. R., Williamson, L. L., Rodbumrer, J., Torsvik, V., Goodman, R. M., and Handelsman, J. 2008. Recovery, purification, and cloning of highmolecular-weight DNA from soil microorganisms. Applied and Environmental Microbiology, 74 (10), 3302-3305.

[79] Gabor, E. M., De Vries, E. J., and Janssen, D. B. 2004. Construction, characterization, and use of small-insert gene banks of DNA isolated from soil and enrichment cultures for the recovery of novel amidases. Environmental Microbiology, 6 (9), 948-958.

[80] Mori, T., Kamei, I., Hirai, H., and Kondo, R. 2014. Identification of novel glycosyl hydrolases with cellulolytic activity against crystalline cellulose from metagenomic libraries constructed from bacterial enrichment cultures. Springerplus, 3, 365.

[81] Knietsch, A., Waschkowitz, T., Bowien, S., Henne, A., and Daniel, R. 2003. Construction and screening of metagenomic libraries derived from enrichment cultures: Generation of a gene bank for genes conferring alcohol oxidoreductase activity on Escherichia coli. Applied and Environmental Microbiology, 69 (3), 1408-1416.

[82] Lombard, N., Prestat, E., van Elsas, J. D., and Simonet, P. 2011. Soilspecific limitations for access and analysis of soil microbial communities by metagenomics. FEMS Microbiology Ecology, 78 (1), 31-49.

[83] Daniel, R. 2004. The soil metagenome - A rich resource for the discovery of novel natural products. Current Opinion in Biotechnology, 15 (3), 199-204.

[84] Frisli, T., Haverkamp, T. H. A., Jakobsen, K. S., Stenseth, N. C., and Rudi, K. 2013. Estimation of metagenome size and structure in an experimental soil microbiota from low coverage next-generation sequence data. Journal of Applied Microbiology, 114 (1), 141-51.

[85] Yule, C. M. 2010. Loss of biodiversity and ecosystem functioning in Indo-Malayan peat swamp forests. Biodiversity and Conservation, 19 (2), 393-409.

[86] Kanokratana, P., Uengwetwanit, T., Rattanachomsri, U., Bunterngsook, B., Nimchua, T., Tangphatsornruang, S., Plengvidhya, V., Champreda, V., Eurwilaichitr, L. 2011. Insights into the phylogeny and metabolic potential of a primary tropical peat swamp forest microbial community by metagenomic analysis. Microbial Ecology, 61 (3), 518-28.

[87] Lipson, D. A., Haggerty, J. M., Srinivas, A., Raab, T. K., Sathe, S., and Dinsdale, E. A. 2013. Metagenomic insights into anaerobic metabolism along an Arctic peat soil profile. PLoS One, 8 (5), e64659.

[88] Stopnisek, N., Gubry-Rangin, C., Höfferle, S., Nicol, G. W., MandicMulec, I., and Prosser, J. I. 2010. Thaumarchaeal ammonia oxidation in an acidic forest peat soil is not influenced by ammonium amendment. Applied and Environmental Microbiology, 76 (22), 7626-34.

[89] Bunterngsook, B., Pattanop, K., Taksawan, T., Sutipa, T., Tanaporn, U., Sansanalak, R., Taweerat, V. 2010. Identification and characterization of lipolytic enzymes from a peat-swamp forest soil metagenome. Bioscience, Biotechnology, and Biochemistry, 74 (9), 1848-54. 